\title{
LEARNING MANAGEMENT SYSTEM, AN INNOVATION IN TEACHING LEARNING PROCESS AT UNIVERSITY LEVEL
}

\author{
Muhammad Asif Nadeem ${ }^{1}$, Nosheen Malik ${ }^{2}$, and Shaista Noreen ${ }^{3}$
}

\begin{abstract}
The Learning Management System (LMS) has attained significance in the innovative teaching-learning process at the university level during pandemics. The $21^{\text {st }}$ century saw innovation in technology use and incorporation of LMS in the teaching-learning process. The major objective of the present study was to determine the teacher-learner perception towards the adaptation of the Learning Management System and to examine the adoption baseline for LMS by incorporating critical external factors in the technology acceptance model. A mixed-method research approach was used. Data was collected from 400 learners and 20 teachers. It was found that teacher's perception of LMS is affected by a number of factors related to social influence, perceived ease of use and usefulness. In addition, factors such as actual use of the system and content qualities are also important to whether teachers embrace a system or not.
\end{abstract}

Keywords: Innovation; Learning; Teaching; Learning Management System (LMS); Educational Technologies; Information Communication Technologies.

\section{INTRODUCTION}

The world of higher education is changing. Increasing pricing, limited resources and rising demands for education are forcing educational institutions to reconsider innovative means of teaching and learning at the university level. This rapid revolutionary environment of education demands the use of LMS extensively at universities (Wagner, Hassanein, \& Head, 2008). Modern LMS models have been originated from conventional distance learning that was designed to educate the pupils in remote and rural areas. Technological advancement is the key

\footnotetext{
${ }^{1}$ Assistant Professor, Department of Education, IUB.asif.nadeem@iub.edu.pk

${ }^{2}$ Assistant Professor, Department of Education, IUB. Nosheen.malik@iub.edu.pk

${ }^{3}$ Assistant Professor, Department of Education, IUB.shaista.noreen@iub.edu.pk

* Corresponding Author
} 
factor for the education change and reform which started through radio broadcasting in 1920 (Huynh, Umesh, \& Valacich, 2003). This innovation was further enhanced through the invention of the internet and social media (Gunasekaran, McNeil, \& Shaul, 2002; Teo \& Gay, 2006). The sudden growth in the use of LMS has revolutionized the education sector and has made it more effective in the teaching-learning process in advanced countries like America, Germany, England and China. However, in emerging countries like Pakistan, the education sector still depends on the traditional teaching methods but they too had to convert their learning modes to the use of LMS during the current upheaval of the pandemic. New technology-based teaching learning modules are promoted to deliver curriculum-wide education and create resources for meaningful contact between teachers and learners in ways that were impossible before. LMS is developed as a combination of appropriate methods for the development, transformation and reformation among educational systems. Improving the scope of education, gaining power for the educational significance, allows using LMS in the transition of teaching learning to energize and make teaching a pleasant, exciting and active process (Taimur-ul-Hassan, 2013). Teaching and learning is a primer mechanism intended to allow learners and teachers to develop the skills, attitudes and competencies needed to successfully serve their duties in the classroom, schools and to the general community. Learning is related to teaching knowledge and skill development, which allows the teacher to fulfil the standards of the profession and to confront challenges. The quality and degree of the learner achievement are mostly decided by the teacher's knowledge, competence and enthusiasm (O'Neill, 1986).

The use of modern technologies like LMS, blended learning and ICT's to improve the education quality of teachers in a formal and organized process is called innovative educational technology. This innovation and teaching learning management includes teaching content, strategies, work organization and interactions through an innovative learning management system. Terminological innovations arise primarily because of the approach to the technological features along with the use of advanced equipment and not because they specifically contribute to education. Their real usability is understood in pedagogical subjects. The use of educational technologies requires expertise in a number of areas; such as pedagogy, psychology, teaching, information science, computer science and others. This variety often contributes to the general understanding of education technology, where each teacher has to align in accordance with their teaching needs (Lazar, 2015). The three areas identified as main 
avenues for the application of educational technologies include, i) as a tutor (instruction and guidance given by computer); ii) as a teaching tool; iii) as a learning tool.

Furthermore, Lazar (2015) specifically concentrated on the educational importance of technologies and software used in the educational technology that appeared to be effective in learning. In addition, several scholars such as Clements and Sarama (2003); Dynarski et al. (2007); Glaubke (2007) proposed five fields of digital systems, having the ability to strongly affect the learning environment. These are five fields include i) Program's educational value ii) Ease of use, iii) The capacity to involve learners in learning, iv) the learner's and program's interactivity, $v$ ) the probability that a system tracks the improvement of the learner. It is clear from the critics such as Morrison, Ross, Morrison, and Kalman (2019) argue that using educational technologies, pupils might advance individually in mastering teaching materials, repeat the content that is not clear enough, collect the results immediately after the test taken and their progress can be tracked.

\section{RESEARCH OBJECTIVES}

This research was designed to achieve the following objectives:

1. To determine the perception of teachers and learners towards the adaptation of the Learning Management System.

2. To identify the prospective teacher role in developing skill acquisition through Learning Management System.

3. To assess the problem faced in the teaching learning process while using LMS.

\section{LITERATURE REVIEW}

The Learning Management System (LMS) is a general concept widely used to describe the different programs of online learning facilities to teachers, students, managers and administrators. Ninoriya, Chawan, and Meshram (2011) believe that LMS is a program that allows automating management and training activities. The learning management system plays a significant part in the online learning environment and can help teachers in the academic success of students (Moorhouse, 2020). Pupils can use LMS to access learning materials through web browsers while using a desktop, laptop or any other mobile device. LMS allows the pupils to interact with their tutors as well as with each other by providing them platforms for sharing knowledge, online examinations and uploading online assignments (Jurubescu, 2008). 
LMS offers many advantages for the learning environment. These can be counted as elimination of physical location, accessibility, provides an attractive environment and incorporation of most of the LMSs with any missing content (Android, Windows and IOS) (Davis, Kong, McBride, \& Morrison, 2017). The use of video games for educational purposes can attract both children and adolescents, in terms of their performance and the results they achieve (Simões, Redondo, \& Vilas, 2013). Learning Management System brings together all these students in a virtual environment that improves both their discussion experiences and feedback (Alam, Hadgraft, \& Alam, 2014).

Since online curriculum are designed essentially to teach remotely, motivation is the main part of the learning procedure in online learning, as in traditional education (I. M. Khan, 2009) and prerequisite for effective online learning (Lim, 2004). Learning is more individual and autonomous in online learning; thus self-motivation is a must to learn effectively. Several studies on online learning have found ties among motivation and results (Saadé, He, \& Kira, 2007), achievement (Bilgiç, Doğan, \& Seferoğlu, 2011), dropout rates (Vallerand \& Blssonnette, 1992) and qualified learning (Grolnick \& Ryan, 1987). These findings stress the importance of online inspiration. In comparison, Newby, Stepich, Lehman, and Russell (2006) point to the fact that technology usage in learning environment has both benefits and motivational drawbacks according to the instructional approach. Given the constant demand for university-based support from students, particularly when using online resources, management support plays an important part in facilitating the LMS technology acceptance (Alharbi \& Drew, 2014; Bousbahi \& Alrazgan, 2015). Previous research studies show that an individual's perception of ease of use (Alharbi \& Drew, 2014; Joshi, Vinay, \& Bhaskar, 2020; McFarland \& Hamilton, 2006; Amin \& Sundari, 2020) and usefulness (Bousbahi \& Alrazgan, 2015; Kim, Kim, Aiken, \& Park, 2006; Lewis, Agarwal, \& Sambamurthy, 2003) of technology are positively linked to the management support. In a blended learning environment student will be unsatisfied by LMS if no proper management support is provided.

Generally speaking, all the LMSs have common features such as; discussion boards, submission of assignments, final reports and review of lectures. However, some features are only available in some LMS mechanisms for example safe assignment submission is a unique feature of Blackboard LMS (Poulova, Simonova, \& Manenova, 2015; Rozac, Ballester, \& Buendía, 2012).

Relating LMS workability and its effectiveness on human capital, Khairudin et al. (2016) described five key elements in the perspectives of human capital; where some indicators are 
also listed below under each criterion along with examples, 1) strengthen the understanding of teachers of contemporary technologies, 2) increasing the contributions of learners in cooperative communication in learning, 3) increasing the educational integrity of learners, 4) giving more opportunities for the involvement of students and the degree of student responsibility in distance learning courses, 5) enhancing the ability of technical operators; for starters. Educational institutes tend to select LMS that helps to be more improved, effective, versatile and strong in their instructional processes.

Research studies are also conducted on investigating the effect of social influence on behavioural intention. Social influence is usually described as a subjective norm which is the effect of an individual within a group. Chu and Chen (2016) investigated the effect of subjective norms especially social identity and social bonds on the adoption of e-learning by extending the theory of planned behaviour. Their findings suggested that subjective norms and social bonds hold optimistic affluence on the behavioural intention towards the adoption of elearning. Researchers also examined the correlation between user's attitudes and perceived behavioural control, which also shows a significant positive co-relation.

Technology Assessment Model (TAM) is considered to be the best-known framework for the perception of technology acceptance by users. This type of research regarding innovative fields have been extensively used and the results have been contradictory (Tarhini et al., 2014). Abdullah and Ward (2016) performed a comparative meta-analysis on 107 e-learning studies and concluded that: 17 out of 27 (63\%) studies had positive results between CSE and Perceived Usefulness (PU) and 33 out of $41(80 \%)$ had positive results between CSE and Perceived Ease of Use (PEOU). Research conducted on the developing countries (such as Saudi Arabia), has observed that CSE has an impact on PEOU and has no impact on PU (Boateng et al., 2016; Kanwal \& Rehman, 2017; Ramírez Anormaliza et al., 2016). It has been found that PEOU correlates with the CSE, results were found in a study conducted on Jordanian students (Hashim, 2011). Ma et al. (2013) concluded that PU was not influenced by CSE. A study conducted on the Lebanese students also supported that PU, PEOU, SN and quality of life are the main aspects to influence the students' behavioural intention (Tarhini et al., 2014). Another study conducted on the students from Saudi Arabia concluded that CSE has a positive influence on PEOU and PU based on the Technology Acceptance Model (TAM) related study of elearning (Al-Mushasha, 2013). Both Venkatesh and Bala (2008); Venkatesh and Davis, (2000) checked the influence of CSE and argue that CSE impacts PEOU by using the TAM3 model. 
With the advent of technology and technology-based learning in this decade, the education sector has been facing many social, cultural, technological and economic problems. Education technology aims to eliminate these issues by designing new methods, templates and tools to make teaching learning easier (Januszewski \& Molenda, 2013). The Covid-19 pandemic has not ended at the national boundaries. It has affected the populations regardless of their race, level of education, income or gender and there were no exceptions to education. The lockdown concerning Covid-19 had disrupted traditional education, most of which lasted more than ten weeks. The educational sector worked together to ensure the continuity of learning from afar via the internet, television and radio mediums. Thus, the teachers have had to respond to

\section{METHODOLOGY}

A mix method research design was used for the present study (Quantitative \& Qualitative) as this is the most reliable research method used in the field of education. According to (Creswell, 2012), a mix method approach is a procedure for collecting, investigating both quantitative and qualitative to examining a research problem. In quantitative method researcher used survey method for collecting the data and statistically analyzing it. However qualitative data such as, open ended interview is used for cross verifying the results of already statistically analyzed data. In education, these problems have a wide variety, thus, mix method approach was used by the researchers to identify the role of Learning Management Systems. Depending on the nature of problem, the researcher has adapted the mix method; including survey as well as interview method.

In the quantitative method, the researchers used the survey method for collecting and statistically analyzing the data. Quantitative analysis includes gathering data in order to test hypotheses or to address the questions related to the current state of the topic of the study. The researchers conducted the study by inductive reasoning (specific to general). The population of the present study consisted of respondents from the public teacher training institute and universities of southern Punjab. According to National Accreditation Council for Teacher Education (NACTE) Pakistan, there are 270 Public and private teacher training institutes in Pakistan and approximately 35 Public teacher training institutes in Punjab. There are seven public teacher training institutes in southern Punjab. Teacher training programs are being currently conducted in public universities; therefore, the researchers selected four universities (given in table 1) through a convenient sampling technique. Under selected ranges of specific demographical variables, the respondents were selected to make the survey sample 
homogeneous. Demographical variables that were considered for this specific study include age, gender, educational level, internet experience and previous experience of LMS.

Table 1. Distribution of Sample

\begin{tabular}{|c|c|c|c|c|}
\hline \multirow[b]{2}{*}{ District } & \multirow[b]{2}{*}{ Institute Name } & \multirow{2}{*}{$\begin{array}{l}\text { Enrolled } \\
\text { Students }\end{array}$} & \multicolumn{2}{|c|}{ Sample } \\
\hline & & & $\begin{array}{c}\text { No. of } \\
\text { Students }\end{array}$ & $\begin{array}{l}\text { No. of } \\
\text { Faculty }\end{array}$ \\
\hline \multirow{2}{*}{ Bahawalpur } & The Islamia University & 1000 & 100 & 5 \\
\hline & $\begin{array}{l}\text { Govt. Sadiq College } \\
\text { Women University }\end{array}$ & 1000 & 100 & 5 \\
\hline Multan & $\begin{array}{c}\text { Bahau-din Zakariya } \\
\text { University }\end{array}$ & 1000 & 100 & 5 \\
\hline $\begin{array}{c}\text { Rahim Yar } \\
\text { Khan }\end{array}$ & $\begin{array}{c}\text { The Islamia University } \\
\text { Rahim Yar Khan } \\
\text { Campus }\end{array}$ & 1000 & 100 & 5 \\
\hline Total & 4 & 4000 & 400 & 20 \\
\hline
\end{tabular}

Source: Study Analysis

The research tool comprised of two sections; the first section included the nominal scales to gather the demographic data of respondents, while the second section comprised the subjective measures to measure the perception of respondents towards the planned model. A five-point Likert scale ranging from "strongly disagree" to "strongly agree" was used to measure all the items of the research tool. A questionnaire was developed for the respondents (learners) whereas; an interview was developed for the teachers. The reliability of the tool was ensured through pilot study testing. The tool was also validated by sending it to the experts and suggestions made by the experts were incorporated.

Table 2. Cronbach Alpha Value of Scale

\begin{tabular}{cc} 
Cronbach's Alpha & No. of Items \\
\hline .976 & 38 \\
\hline Source: Study Analysis &
\end{tabular}

The theoretical framework of the research was developed under two theories that were Theory of Planned Behavior (TPB) and the Technology Acceptance Model (TAM). TPB model is used to understand decision making in a manner intended for understanding a specific behavior, it measures the strength of a specific behavior possessed by an individual to show their 
engagement (Ajzen, 1991). Davis (1985) introduced the technology acceptance model; "TAM referred to computer use but is particularly well-suited to model the computer acceptance, as it integrates the results compiled from more than a decade of information system research.

The questionnaire for the respondents consisted of 20 items in total; 18 items were close-ended whereas; 1 item was semi close-ended and the last item was open-ended asking about the respondents' suggestions about the topic. Four (4) questions were about subjective norms, five (5) were about computer self-efficacy, two (2) questions were related to internet experience, two (2) inquired about management support, three were about training, and four questions were related to question about perceived usefulness, The interview for the teachers consisted of eight items. All the items were open-ended. Before the interview was conducted a form was distributed among the respondents to collect their demographic data.

\section{DATA ANALYSIS}

For the distribution of the gender who partook in this survey; female participants were 215 and male participants were 164. So, the female participants who took part in this data were 56.7 percent while the number of males who took part in this survey was 43.3 percent.

Table 3. Institution-Wise Distribution of Learners

\begin{tabular}{lcccc}
\hline & Frequency & Percent & Valid Percent & $\begin{array}{c}\text { Cumulative } \\
\text { Percent }\end{array}$ \\
\hline Male & 164 & 43.3 & 43.3 & 43.3 \\
Female & 215 & 56.7 & 56.7 & 100.0 \\
\hline Total & 379 & 100.0 & 100.0 & \\
\hline Source: Study Analysis & & &
\end{tabular}

Table 4. Educational-Wise Distribution of Learners

\begin{tabular}{ccccc}
\hline Frequency & Percent & Valid Percent & \multicolumn{2}{c}{ Cumulative Percent } \\
\hline $1^{\text {st }}$ & 70 & 18.5 & 18.5 & 18.5 \\
$2^{\text {nd }}$ & 29 & 7.7 & 7.7 & 26.1 \\
$3^{\text {rd }}$ & 60 & 15.8 & 15.8 & 42.0 \\
$4^{\text {th }}$ & 91 & 24.0 & 24.0 & 66.0 \\
$5^{\text {th }}$ & 33 & 8.7 & 8.7 & 74.7 \\
$6^{\text {th }}$ & 6 & 1.6 & 1.6 & 76.3 \\
$7^{\text {th }}$ & 37 & 9.8 & 9.8 & 86.0 \\
$8^{\text {th }}$ & 53 & 14.0 & 14.0 & 100.0 \\
\hline Total $^{\text {Tourc: }}$ & 379 & 100.0 & 100.0 & \\
\hline
\end{tabular}

Source: Study Analysis 
The respondents were divided into two categories that were undergraduates and graduates, further they were divided into those semesters where they had already got themselves equipped with micro-teaching and prospective teacher training skills. According to which 18.5 percent of the respondents were from $1^{\text {st }}$ semester, 7.7 percent of the respondents were prospective teachers who were studying in $2^{\text {nd }}$ semester, 15.8 percent of the prospective teachers were in $3^{\text {rd }}$ semester, and 24 percent of the respondents were taking training in $4^{\text {th }}$ semester i.e. B.S in Education.

Table 5. Learning Management System (LSM) Experience of Learners

\begin{tabular}{|c|c|c|c|c|}
\hline & Frequency & Percent & Valid Percent & Cumulative Percent \\
\hline Yes & 319 & 84.2 & 84.2 & 84.2 \\
\hline No & 60 & 15.8 & 15.8 & 100.0 \\
\hline Total & 379 & 100.0 & 100.0 & \\
\hline
\end{tabular}

Table 5 shows the percentage of semester wise participants. According to the table, 84.4 percent of prospective teachers have experience of learning management systems and 7.1 percent of prospective teachers have no experience of learning management systems.

Table 6. Descriptive Statistics - Role of Learning Management System in Teaching Learning

\begin{tabular}{lcccccccc}
\hline & N & Min & Max & Mean & S. D & Variance & Skewness & Kurtosis \\
\hline SN & 379 & 4 & 20 & 14.89 & 3.959 & 15.673 & -.674 & -.038 \\
CSE & 379 & 5 & 25 & 18.42 & 4.881 & 23.821 & -.665 & -.060 \\
IE & 379 & 2 & 10 & 7.68 & 2.327 & 5.415 & -.896 & -.200 \\
MS & 379 & 2 & 10 & 7.44 & 2.179 & 4.750 & -.652 & -.397 \\
T & 379 & 3 & 15 & 10.68 & 3.294 & 10.853 & -.462 & -.679 \\
PU & 379 & 5 & 25 & 17.59 & 5.724 & 32.760 & -.438 & -.788 \\
PEOU & 379 & 2 & 10 & 6.92 & 2.382 & 5.673 & -.524 & -.726 \\
BIU & 379 & 6 & 30 & 21.20 & 6.622 & 43.855 & -.640 & -.394 \\
ATU & 379 & 3 & 15 & 10.87 & 3.484 & 12.138 & -.676 & -.455 \\
AU & 379 & 6 & 30 & 21.67 & 6.243 & 38.979 & -.667 & -.241 \\
\hline
\end{tabular}

Valid $N$ (list wise) $=379$

TPB: Theory of Planned Behavior; TRA: Theory of Reasoned Action; BI: Behavioral Intention; AU: Actual Use, ATU: Attitude Towards Use

Table 6 shows that mean score of Subject Norms with values $M=14.89, \mathrm{SD}=3.99$ demonstrate the positive variance of analysis (15.673, Skewness = -.674 and Kurtosis = -.038). For Computer Self-Efficacy values $\mathrm{M}=18.42, \mathrm{SD}=4.88$ show positive variance of analysis (23.821, Skewness $=-.665$ and Kurtosis $=-.060)$. For Internet Experience the values $M=7.68$, 
$\mathrm{SD}=2.327$ show positive variance of analysis $(5.415$, Skewness $=-.896$ and Kurtosis $=-.200)$. Values of Management Support $(M=7.44, S D=2.179)$ show positive variance of analysis (4.750, Skewness $=-.652$ and Kurtosis $=-.397)$. Training $(M=10.68, \mathrm{SD}=3.294)$ shows positive variance of analysis $(10.853$, Skewness $=-.462$ and Kurtosis $=-.679)$. The variable Perceived Use $(\mathrm{M}=17.59, \mathrm{SD}=5.724)$ shows positive variance of analysis $(32.760$, Skewness $=-.438$ and Kurtosis $=-.788)$. Whereas Perceived Ease of Use $(\mathrm{M}=6.92, \mathrm{SD}=2.382)$ shows positive variance of analysis (5.673, Skewness $=-.524$ and Kurtosis $=-.726$ ). Similarly, Behavioral Intention to Use $(\mathrm{M}=21.20, \mathrm{SD}=6.622)$ shows positive variance of analysis $(43.855$, Skewness $=-.640$ and Kurtosis $=-.394)$. Lastly, Attitude towards Use $(M=10.87, \mathrm{SD}$ = 3.484) and Actual Use $(\mathrm{M}=21.67, \mathrm{SD}=6.243)$ show positive variance of analysis $(12.138$, Skewness $=-.676$ and Kurtosis $=-.455)$ and $(38.979$, Skewness $=-.667$ and Kurtosis $=-.241)$, respectively.

Table 7. Learner' Opinions about Perceived Use of LMS

\begin{tabular}{|c|c|c|c|c|c|c|c|c|c|c|}
\hline Statement & $\begin{array}{c}\text { SA } \\
\%\end{array}$ & $\begin{array}{l}\mathrm{A} \\
\%\end{array}$ & $\begin{array}{c}\mathrm{UN} \\
\%\end{array}$ & $\begin{array}{c}\mathrm{DA} \\
\%\end{array}$ & $\begin{array}{c}\text { SDA } \\
\%\end{array}$ & M & SD & $\mathrm{t}$ & $\mathrm{p}$ & MD \\
\hline $\begin{array}{l}\text { PU1: The LMS enhances my } \\
\text { learning capabilities. }\end{array}$ & 31.9 & 26.4 & 23.7 & 11.9 & 6.1 & 3.66 & 1.211 & 58.852 & .000 & 3.662 \\
\hline $\begin{array}{l}\text { PU2: The LMS enhances my } \\
\text { learning productivity. }\end{array}$ & 30.9 & 24.0 & 21.4 & 16.1 & 7.7 & 3.54 & 1.285 & 53.691 & .000 & 3.544 \\
\hline $\begin{array}{l}\text { PU3: The LMS enhances my } \\
\text { learning effectiveness. }\end{array}$ & 27.4 & 23.7 & 25.3 & 13.5 & 10.0 & 3.45 & 1.293 & 51.967 & .000 & 3.451 \\
\hline $\begin{array}{l}\text { PU4: I can achieve my tasks } \\
\text { more quickly with LMS. }\end{array}$ & 28.2 & 29.6 & 19.3 & 15.0 & 7.9 & 3.55 & 1.262 & 54.798 & .000 & 3.551 \\
\hline $\begin{array}{l}\text { PU5: It is easy to learn course } \\
\text { content with the help of LMS. }\end{array}$ & 29.0 & 21.1 & 23.5 & 12.1 & 14.2 & 3.39 & 1.386 & 47.562 & .000 & 3.385 \\
\hline Perceived Use & 29.5 & 25 & 22.6 & 13.7 & 9.2 & 3.51 & 1.287 & 53.374 & .000 & 3.518 \\
\hline
\end{tabular}

Prospective teachers were asked to give their opinion about the statement that "LMS enhances their learning capabilities". The majority of the prospective teachers' (31.9 percent) strongly agreed, $26.4 \%$ of participants agreed, $23.7 \%$ were undecided, $11.9 \%$ neither disagreed whereas $8.4 \%$ of teachers strongly disagreed with the statement that the LMS enhances their learning capabilities. Thus retrieved data and a higher propensity of agreeableness indicated that the LMS enhances their learning capabilities. 
Similarly, the mean value of table 7 identified that the respondents disagreed with the statement that the LMS enhances their learning capabilities and a standard deviation of 1.211 also showed that the value is significant.

The statements identified that $30.9 \%$ of respondents are strongly agreed with the statement that LMS enhances their learning productivity, $24 \%$ of teachers agreed with the statement, whereas $21.4 \%$ of respondents were undecided, $16.1 \%$ of respondents disagreed while 7.7 percent of respondents show strong disagreement that LMS enhances their learning productivity. The majority 54.9 percent of the respondent agreed with the statement, and the standardized mean value of 3.54 and standard deviation of 1.285 confirms agreement with the statement, also the t-value of 53.691 is significant at 0.000 and shows a statistically significant tendency towards the agreement.

Moreover, $27.4 \%$ of prospective teachers strongly agreed with the statement that LMS enhances their learning effectiveness, $23.7 \%$ of prospective teachers agreed with the statement, whereas $25.3 \%$ of prospective teachers are undecided, $13.5 \%$ of prospective teachers have disagreed and $10 \%$ of prospective teachers are strongly disagreed with the statement that the LMS enhances their learning effectiveness. The majority 51.1 percent of teachers agreed with the statement, and the standardized mean value of 3.45 and standard deviation of 1.293 illustrate the statement agreement. The t-value of 51.967 is also significant at 0.000 and shows a statistically significant preference towards agreement.

The statements identified that $28.2 \%$ of prospective teachers are strongly agreed with the statement that they can achieve their tasks more quickly with LMS, 29.6\% of prospective teachers agreed with the statement, whereas $19.3 \%$ of prospective teachers were undecided, $15 \%$ of teachers disagreed whereas 7.9 percent of prospective teachers strongly disagreed that they can achieve their tasks more quickly with LMS. Thus the majority 57.8 percent of prospective teachers agreed with the statement (standardized mean value 3.55, standard deviation 1.262, t-value 54.798 significant at 0.000 indicates this willingness towards an agreement is statistically significant.

The statements indicate that $29 \%$ of respondents are strongly agreed with the statement that it was easy to learn course content with the help of LMS, $21.1 \%$ of teachers agreed with the statement, whereas $23.5 \%$ of respondents were undecided, $12.1 \%$ of respondents disagreed whereas $14.2 \%$ of prospective teachers strongly disagreed with the statement that it was easy to learn course content with the help of LMS. Hence, the majority (50.1 percent) of teachers 
agreed with the statement (standardize mean value 3.39 and standard deviation 1.386) indicating agreement with the statement and with t-value 47.562 significant at 0.000 indicates that this proclivity for consensus is statistically significant.

The collected data shows $29.5 \%$ of prospective teachers strongly agreed with the statement that role of learning management system in perceived use, $25 \%$ of prospective teachers agreed with the statement, whereas $22.6 \%$ of prospective teachers were undecided, $13.7 \%$ of prospective teachers disagreed whereas $9.2 \%$ of prospective teachers strongly disagreed about the role of learning management system in perceived use. Hence, the majority $(54.5 \%)$ of prospective teachers agreed with the statement (standardized mean value 3.51 and standard deviation 1.287) indicating a strong agreement towards the statement. Also the t-value 53.374 significant at 0.000 shows that this proclivity for consensus is statistically significant.

Table 8. Bivariate Correlation about the Role of Learning Management System in Teaching Learning

\begin{tabular}{|c|c|c|c|c|c|c|c|c|c|c|}
\hline & 1 & 2 & 3 & 4 & 5 & 6 & 7 & 8 & 9 & 10 \\
\hline \multirow[t]{2}{*}{ 1. Subjective Norm } & 1 & $.684^{* *}$ & $.604^{* *}$ & $.541^{* *}$ & $.432^{* *}$ & $.586^{* *}$ & $.579^{* *}$ & $.688^{* *}$ & $.570^{* *}$ & $.588^{* *}$ \\
\hline & & .000 & .000 & .000 & .000 & .000 & .000 & .000 & .000 & .000 \\
\hline \multirow{2}{*}{ 2. Computer Self Efficacy } & & 1 & $.760^{* *}$ & $.701^{* *}$ & $.637^{* *}$ & $.685^{* *}$ & $.660^{* *}$ & $.697^{* *}$ & $.653^{* *}$ & $.704^{* *}$ \\
\hline & & & .000 & .000 & .000 & .000 & .000 & .000 & .000 & .000 \\
\hline \multirow{2}{*}{ 3. Internet Experience } & & & 1 & $.669^{* *}$ & $.552^{* *}$ & $.644^{* *}$ & $.614^{* *}$ & $.674^{* *}$ & $.659^{* *}$ & $.582^{* *}$ \\
\hline & & & & .000 & .000 & .000 & .000 & .000 & .000 & .000 \\
\hline \multirow{2}{*}{ 4. Management support } & & & & 1 & $.661^{* *}$ & $.682^{* * *}$ & $.682^{* *}$ & $.678^{* *}$ & $.624^{* *}$ & $.670^{* *}$ \\
\hline & & & & & .000 & .000 & .000 & .000 & .000 & .000 \\
\hline \multirow{2}{*}{ 5. Training } & & & & & 1 & $.581^{* *}$ & $.549^{* *}$ & $.544^{* *}$ & $.591^{* *}$ & $.632^{* *}$ \\
\hline & & & & & & .000 & .000 & .000 & .000 & .000 \\
\hline \multirow{2}{*}{ 6. Perceived use } & & & & & & 1 & $.805^{* *}$ & $.867^{* *}$ & $.857^{* *}$ & $.743^{* *}$ \\
\hline & & & & & & & .000 & .000 & .000 & .000 \\
\hline \multirow{2}{*}{ 7. Perceived ease of use } & & & & & & & 1 & $.826^{* *}$ & $.818^{* *}$ & $.732^{* *}$ \\
\hline & & & & & & & & .000 & .000 & .000 \\
\hline \multirow{2}{*}{ 8. Behavioral intention to use } & & & & & & & & 1 & $.884^{* *}$ & $.822^{* * *}$ \\
\hline & & & & & & & & & .000 & .000 \\
\hline \multirow[t]{2}{*}{ 9. Attitude towards use } & & & & & & & & & 1 & $.770^{* *}$ \\
\hline & & & & & & & & & & .000 \\
\hline 10. Actual use & & & & & & & & & & 1 \\
\hline
\end{tabular}

**. Correlation is significant at the 0.01 level (2-tailed).

Table 8 details the results of matrix of Pearson's correlation which indicates that role of LMS in blended learning is significantly allied with subject $(\mathrm{r}=.588 * *)$, computer self-efficacy $(.684 * *)$, study extra material $(r=0.342)$, organizing assignments $(r=0.425)$, focus on theme/main idea $(r=0.2580)$, following of timeline $(r=0.311)$ and following of rules $(r=$ 
0.402). Note taking amongst higher achievers has insignificant association with emphasis on theme/main idea $(\mathrm{r}=.117, \mathrm{p}=.103)$ though note taking is significantly associated with study extra material $(r=0.193)$, following timeline $(r=0.304)$, organization of assignments $(r=0.202)$ and following of rules $(r=0.210)$ by students. Study extra material significantly relate to following of timeline $(r=0.276)$, main idea emphasis $(r=0.405)$, organization of assignments $(r=0.320)$ and rules following $(r=0.340)$. Following the timelines by students with higher achievements is significantly linked with emphasize on main idea $(\boldsymbol{r}=0.246)$ and organization of assignments $(\boldsymbol{r}=0.419)$ and rule following $(\mathrm{r}=.472)$. Focusing on main idea by students with high achievements have been significantly related with organizing assignments $(\mathbf{r}=0.330)$ and following of rules $(\mathbf{r}=0.240)$. Similarly, organization of assignments and rule following amongst students with higher achievement are significantly linked with one another $(r=.465)$.

\section{Qualitative Analysis of Data}

The majority of the teachers ( $82 \%$ ) believed that they had a good experience of teaching. $16 \%$ percent of respondents underwent difficult experience about teaching through LMS. The teachers were divided into two groups on their opinion about learning objectives achieved more effectively through LMS, a) learning objectives achievement at learner's end; and b) teaching objectives achievement at the teacher's end. The majority of the defendants (72.72 percent) thought that learning objectives at the learner's end cannot be effectively achieved by teaching through LMS. 18.18 percent of teachers think that learning objectives can be effectively achieved by teaching through LMS whereas 10 percent were uncertain about the effective achievement of learning objectives through LMS. Considering the achievement of teaching objectives at the teacher's end; 63.63 percent of teachers think that teaching objectives can be effectively achieved by teaching through LMS. Whereas 36.36 percent were in favor that teaching objectives cannot be achieved effectively through LMS. The teachers delineated their judgment about using LMS during COVID-19. It was observed that majority of the 90 percent agreed with the statement that LMS is good for teaching-learning process during the pandemic situation while only 10 percent preferred physical lectures.

View of teachers about LMS providing the complete package of teaching and learning was recorded. It was witnessed that 36.36 percent of teachers considered LMS as a complete package whereas 36.36 percent teachers believed that LMS is not a complete package of teaching and training. 27.27 percent of the total respondents believed that this software is near to complete. Considering the teachers' opinion about the usability of LMS it was found that 
36.36 percent of participants think that LMS usability is above average whereas 63.63 percent of respondents think that LMS usability is average. Data retrieved showed different opinions on teachers making teaching learning more effective through LMS. Minority advocated that the LMS software interface must include features like simplicity and efficiency and the user interface of LMS must be interactive and flexible to use. The majority of the respondents were in the favor of proper training for teachers as well as for students be given to make the teaching learning through LMS more effective. In the light of these suggestions, it was concluded that 80 percent emphasized the provision of proper training provided by the organization whereas 20 percent accentuated the introduction of more features to the LMS interface.

\section{DISCUSSION}

Most of the intention-based research has proposed that internal perception and external behavior are closely linked, both affecting each other, as internal perception is changed by external behaviors as well as external behaviors are driven by individual internal perceptions. A lot of research studies have been carried out on investigating the effect of social influence on behavioral intention. Social influence is usually described as the subjective norm which is the effect of an individual within a group. Chu and Chen (2016) had investigated the effect of subjective norms especially social identity and social bonds on the acceptance of LMS by extending the theory of planned behavior. Their findings suggested that subjective norm and social bonds had a positive effect on behavioral intention to acceptance of teaching and learning.

Moreover, TAM is considered to be one of the best-known frameworks for the perception of technology acceptance by users. TAM related research in the area of e-learning CSE has been extensively used and the results have been contradictory (Tarhini et al., 2014). Abdullah and Ward (2016) performed a comparative meta-analysis on 107 e-learning studies and concluded that 17 out of 27 (63\%) studies had positive results between CSE and PU and 33 out of 41(80\%) had positive results between CSE and PEOU. Boateng et al. (2016); Kanwal and Rehman (2017); Ramírez Anormaliza et al. (2016) researched developing countries (such as Saudi Arabia \& Pakistan) and observed mixed results asserting CSE to have an impact on PEOU and had no Impact on PU.

The previous studies explain how organizational support affects the self-efficacy of LMS, technological support and perceived benefits of faculty. The results strengthen the objectives of the research that organizational support plays a significant role in increasing the LMS control 
and technical assistance of the faculty. The universities can enhance the use of LMS and produce productive results by structuring the organizations of their faculty to properly serve both the professional and self-effective teaching in the web-based teacher training and webbased curricula (Zheng et al., 2018). The present study investigated the effect of teachinglearning. A significant correlation was found with standardized mean and standard deviation of 1.205 and 1.262 respectively being significant at 0.000 . The findings of the present research are in correlation with the previous study findings.

\section{CONCLUSION}

The majority of the learners identified that they can complete the task on the Learning Management System (LMS) on their own. The induction of training helped improve teachers' computer self-efficacy and LMS capabilities and made them confident in using the user manual as a guide and reference. The majority of teachers agreed that their prior internet learning experience was helpful and gave them confidence in learning through the learning management system. Their institutes also highlighted the importance of the learning management system and administration identifies the importance of the learning management system as a tool to complete university modules. Therefore, through research, this issue should be addressed and help build a better understanding of teaching learning practices through LMS. Teachers can overcome problems by handling instructional content, tasks and notifications, as the use of the learning management system facilitates collaborations with learners. Although, some teachers were disappointed because LMS increased their workload. The learning management system (LMS) however is seen to enhance their learning capabilities, productivity and effectiveness. It is easy to learn course content with the help of LMS. Finally, it is concluded that research and teaching experiences must be managed and matched with blended learning techniques to achieve an improved and more fruitful instructional environment using LMS and in a way, the advantages of face to face and online teaching should be best exploited.

\section{PRACTICAL IMPLICATIONS AND RECOMMENDATIONS}

1. Teachers are expected to integrate LMS with conventional learning and be proficient in web-based education.

2. Teacher training institutes must build the expertise of learners for the use of offline as well as online e-resources and even in blended learning.

3. A cohesive and improved learning experience should be provided with high-quality educational materials designed for the traditional curriculum. 
4. E-content should be designed in a way that can be used through different e-learning software. It is, therefore, necessary to ensure that the material presented is following the methodologies used in different institutes and is thus more likely to lead to good learning.

5. In Pakistan, there is a significant variation in the usage of LMS in urban and rural areas. In addition, the availability of facilities does not ensure their full utilization. Lastly, it is concluded that in handling the "internet divide" dilemma at academic universities, appropriate input on government entities, and overseeing and monitoring university education is crucial.

\section{FINAL ANALYSIS AND A WAY FORWARD}

The opinion of teachers regarding the use of LMS in future was recorded in this study and it was clear from the data that teachers were in favor of using LMS in future. Because the $21^{\text {st }}$ century is the age of information technology and it is the need of the day to learn IT. The prospective teachers must be equipped with the fifth skill of communication along with the other four skills. Knowledge of IT is considered the fifth skill of communication. All the teacher respondents strongly suggested the use of LMS in future. However, few of them suggested that only $10 \%$ of course content during the training of prospective teachers should be taught through LMS in conventional teaching. 


\section{REFERENCES}

Abdullah, F., \& Ward, R. (2016). Developing a General Extended Technology Acceptance Model for E-Learning (GETAMEL) by analysing commonly used external factors. Computers in Human Behavior, 56, 238-256.

Ajzen, I. (1991). The theory of planned behavior. Organizational behavior and human decision processes, 50(2), 179-211.

Alam, F., Hadgraft, R. G., \& Alam, Q. (2014). eLearning: Challenges and opportunities. In Using technology tools to innovate assessment, reporting, and teaching practices in engineering education (pp. 217-226): IGI Global.

Alharbi, S., \& Drew, S. (2014). Using the technology acceptance model in understanding academics'z behavioral intention to use learning management systems. International Journal of Advanced Computer Science and Applications, 5(1), 143-155.

Al-Mushasha, N. F. A. (2013). Determinants of e-learning acceptance in higher education environment based on extended technology acceptance model. Paper presented at the 2013 Fourth International Conference on e-Learning" Best Practices in Management, Design and Development of e-Courses: Standards of Excellence and Creativity".

Amin, F. M., \& Sundari, H. (2020). EFL students' preferences on digital platforms during emergency remote teaching: Video Conference, LMS, or Messenger Application?. Studies in English Language and Education, 7(2), 362-378.

Bilgiç, H. G., Doğan, D., \& Seferoğlu, S. S. (2011). Current situation of online learning in Turkish higher education institutions: Needs, problems, and possible solutions. Yükseköğretim Dergisi, 1(2), 80-87.

Boateng, R., Mbrokoh, A. S., Boateng, L., Senyo, P. K., \& Ansong, E. (2016). Determinants of e-learning adoption among students of developing countries. The International Journal of Information and Learning Technology.

Bousbahi, F., \& Alrazgan, M. S. (2015). Investigating IT faculty resistance to learning management system adoption using latent variables in an acceptance technology model. The Scientific World Journal, 2015.

Chu, T.-H., \& Chen, Y.-Y. (2016). With good we become good: Understanding e-learning adoption by theory of planned behavior and group influences. Computers \& Education, 92, 37-52.

Clements, D. H., \& Sarama, J. (2003). Strip mining for gold: Research and policy in educational technology—A response to "Fool's Gold". AACE Journal, 11(1), 7-69. 
Creswell, J. W. (2012). Educational Research: Planning, Conducting, and Evaluating Quantitative and Qualitative Research: Pearson.

Davis, F. D. (1985). A technology acceptance model for empirically testing new end-user information systems: Theory and results. Massachusetts Institute of Technology,

Davis, L. L., Kong, X., McBride, Y., \& Morrison, K. M. (2017). Device comparability of tablets and computers for assessment purposes. Applied Measurement in Education, 30(1), 16-26.

Dynarski, M., Agodini, R., Heaviside, S., Novak, T., Carey, N., Campuzano, L., . . Javitz, H. (2007). Effectiveness of reading and mathematics software products: Findings from the first student cohort.

Glaubke, C. (2007). The effects of interactive media on preschoolers' learning: A review of the research and recommendations for the future. Oakland, CA: Children Now.

Grolnick, W. S., \& Ryan, R. M. (1987). Autonomy in children's learning: An experimental and individual difference investigation. Journal of personality and social psychology, 52(5), 890

Gunasekaran, A., McNeil, R. D., \& Shaul, D. (2002). E-learning: research and applications. Industrial and commercial training.

Huynh, M. Q., Umesh, U., \& Valacich, J. S. (2003). E-learning as an emerging entrepreneurial enterprise in universities and firms. Communications of the Association for Information Systems, 12(1), 3.

Joshi, A., Vinay, M., \& Bhaskar, P. (2020). Impact of coronavirus pandemic on the Indian education sector: perspectives of teachers on online teaching and assessments. Interactive Technology and Smart Education.

Jurubescu, T. (2008). Learning content management system. Revista Informatica Economica, $4(48), 91-94$.

Kanwal, F., \& Rehman, M. (2017). Factors affecting e-learning adoption in developing countries-empirical evidence from Pakistan's higher education sector. IEEE Access, 5, 10968-10978.

Khairudin, N., Khairudin, R., Hamid, M. N. A., Hancock, P., McGill, T., \& Zamani, Z. A. (2016). The importance of human capital perspective in the learning management system (LMS) decision making process at universities. Jurnal Psikologi Malaysia, $30(2)$.

Khan, I. M. (2009). An analysis of the motivational factors in online learning. University of Phoenix. 
Khasawneh, M., \& Yaseen, A. B. (2017). Critical success factors for e-learning satisfaction, Jordanian Universities' experience. Journal of Business \& Management (COES\&RJJBM), 5(1), 56-69.

Kim, D. R., Kim, B. G., Aiken, M. W., \& Park, S. C. (2006). The Influence of Individual, Task, Organizational Support, and Subject Norm Factors on the Adoption of Groupware. Academy of Information \& Management Sciences Journal, 9(2).

Lazar, S. (2015). The importance of educational technology in teaching. International Journal of Cognitive Research in Science, Engineering and Education, 3(1).

Lewis, W., Agarwal, R., \& Sambamurthy, V. (2003). Sources of influence on beliefs about information technology use: An empirical study of knowledge workers. MIS quarterly, 657-678.

Lim, D. H. (2004). Cross cultural differences in online learning motivation. Educational Media International, 41(2), 163-175.

Ma, C. M., Chao, C. M., \& Cheng, B.-W. (2013). Integrating technology acceptance model and task-technology fit into blended e-learning system. JApSc, 13(5), 736-742.

McFarland, D. J., \& Hamilton, D. (2006). Adding contextual specificity to the technology acceptance model. Computers in human behavior, 22(3), 427-447.

Moorhouse, B. L. (2020). Adaptations to a face-to-face initial teacher education course 'forced'online due to the COVID-19 pandemic. Journal of Education for Teaching, 46(4), 609-611.

Morrison, G. R., Ross, S. J., Morrison, J. R., \& Kalman, H. K. (2019). Designing effective instruction: John Wiley \& Sons.

Newby, T., Stepich, D., Lehman, J., \& Russell, J. (2006). Recommended books. Journal of Computing in Higher Education, 18(1), 135.

Ninoriya, S., Chawan, P., \& Meshram, B. (2011). CMS, LMS and LCMS for elearning. International Journal of Computer Science Issues (IJCSI), 8(2), 644.

O'Neill, G. P. (1986). Teacher Education or Teacher Training: Which is it? McGill Journal of Education/Revue des sciences de l'éducation de McGill, 21(003).

Poulova, P., Simonova, I., \& Manenova, M. (2015). Which one, or another? Comparative analysis of selected LMS. Procedia-Social and Behavioral Sciences, 186, 1302-1308.

Ramírez Anormaliza, R. I., Sabaté i Garriga, F., \& Llinàs Audet, F. J. (2016). The acceptance and use of the e-learning systems among the university teachers in Ecuador. Paper presented at the EDULEARN16 Proceedings. 
Rozac, J., Ballester, J. V., \& Buendía, F. (2012). A model-based approach to integrate elearning platforms and social networks using a service-oriented framework. Journal of Research and Practice in Information Technology, 44(3), 247.

Saadé, R. G., He, X., \& Kira, D. (2007). Exploring dimensions to online learning. Computers in human behavior, 23(4), 1721-1739.

Simões, J., Redondo, RD, \& Vilas, AF (2013). A social gamification framework for the K-6 learning platform. Computers in Human Behavior , 29 (2), 345-353.

Taimur-ul-Hassan, A. R. S. (2013). ICTs in learning: Problems faced by Pakistan. Journal of Research, 7(1), 52-64.

Tarhini, A., Hone, K., \& Liu, X. (2014). The effects of individual differences on e-learning users' behaviour in developing countries: A structural equation model. Computers in Human Behavior, 41, 153-163.

Teo, C. B., \& Gay, R. K. L. (2006). A knowledge-driven model to personalize e-learning. Journal on Educational Resources in Computing (JERIC), 6(1), 3-es.

Vallerand, R. J., \& Blssonnette, R. (1992). Intrinsic, extrinsic, and amotivational styles as predictors of behavior: A prospective study. Journal of personality, 60(3), 599-620.

Venkatesh, V., \& Bala, H. (2008). Technology acceptance model 3 and a research agenda on interventions. Decision Sciences, 39(2), 273-315.

Venkatesh, V., \& Davis, F. D. (2000). A theoretical extension of the technology acceptance model: Four longitudinal field studies. Management Science, 46(2), 186-204.

Wagner, N., Hassanein, K., \& Head, M. (2008). Who is responsible for e-learning success in higher education? A stakeholders' analysis. Journal of Educational Technology \& Society, 11(3), 26-36.

Zheng, Y., Wang, J., Doll, W., Deng, X., \& Williams, M. (2018). The impact of organisational support, technical support, and self-efficacy on faculty perceived benefits of using learning management system. Behaviour \& Information Technology, 37(4), 311-319. 